\title{
Does Asymmetric Relation Exist between Exchange Rate and Foreign Direct Investment in Bangladesh? Evidence from Nonlinear ARDL Analysis
}

\author{
Md. QAMRUZZAMAN ${ }^{1}$, Salma KARIM ${ }^{2}$, Jianguo WEI $^{3}$
}

Received: June 18, 2019 Revised: September 16, 2019 Accepted: September 30, 2019

\begin{abstract}
The study aims to investigate the pattern of relationships such as symmetric or asymmetric, between exchange rate and foreign direct investment in Bangladesh by applying Autoregressive Distributed Lagged (ARDL) and nonlinear ARDL. In this study, we employed quarterly data for the period of 1974Q1 to 2016Q4. Data were collected and aggregated from various sources namely, Bangladesh Economic Review published by Ministry of Finance and statistical yearbook published by Bangladesh Bureau of Statistics and an annual report published by Bangladesh Bank. The relationship between exchange rate and FDI inflows attract immense interest in the recent periods, especially for developing countries' perspective. The results of the study ascertain the long run relationship between FDI, exchange rate, monetary policy, and fiscal policy. Considering the asymmetric assumption, the findings from NARDL confirm the existence of a long-run asymmetric relationship in the empirical equation. In the long run, it is observed that positive change that is the appreciation of exchange rate against USD decrease FDI inflows and negative shocks results in grater inflows of FDI, however, the positive shocks produce higher intensity that negative shocks in Exchange rate. For directional causality, the coefficients of error correction term confirm long-run causality, in particular, bidirectional causality unveiled between FDI and exchange rate.
\end{abstract}

Keywords : Exchange Rate, FDI, ARDL, NARDL, Bangladesh

JEL Classification Code : F31, F34

\section{Introduction}

The link between the exchange rate and FDI inflows in the host country is evident in the empirical literature. Existing finance literature including Froot and Stein (1991) emphasized that the depreciation of host country currency can cause a dramatic increase of FDI inwards in the economy. Furthermore, Harris and Ravenscraft (1991)

1 First Author and Corresponding Author, Assistant Professor, School of Business and Economics, United International University, Bangladesh. [Postal Address: United City, Madani Avenue, Badda, Dhaka - 1212, Bangladesh] Email: zaman_wut16@yahoo.com

2 Professor, School of Business and Economics, United International University, Bangladesh. Email: ska@bus.uiu.ac.bd

3 Professor, School of Economics, Wuhan University of Technology, China. Email: weijg@whut.edu.cn

(c) Copyright: Korean Distribution Science Association (KODISA)

This is an Open Access article distributed under the terms of the Creative Commons Attribution Non-Commercial License (http://Creativecommons.org/licenses/by-nc/4.0/) which permits unrestricted noncommercial use, distribution, and reproduction in any medium, provided the original work is properly cited. explained in their study that a depreciation of US dollar largely associated with heavy inflows of FDI in the US economy, likewise the effect of host currency depreciation attract foreign long-term investment in the form of FDI also noticed by other researchers (Dewenter, 1995; Klein \& Rosengren, 1994; Bayoumi, Bartolini, \& Klein, 1996). Empirical literature suggested that the nexus between FDI exchange rates largely investigated with two assumptions either depreciation of host currency relatively encourage large inflows of FDI, or exchange rate fluctuation negatively influence on FDI inflows in the economy. With this study, we further moved towards investigating the existence of a nonlinear relationship between exchange rate and FDI inflows in Bangladesh by applying nonlinear Autoregressive Distributed lagged model proposed by Shin, Yu, and Greenwood-Nimmo (2014). So as to investigating FDI and exchange rate relationship in this study we decomposed both FDI and exchange rate in positive and negative shock for the purpose of unveiling the effect pattern from FDI inflows on the exchange rate and exchange rate on FDI inflows, 
respectively.

As determinants of FDI inflows, several empirical studies including Liu (2010), Shapiro and Globerman (2003), and Ang (2008), exposed that host country exchange rate play a critical deterministic role in the process of inflows of FDI. Exchange rate volatility influences every core ingredients in the economy such as international trade performance, aggregated production, inflation and foreign investment in the host country. The nexus between foreign direct investment (FDI) and exchange rates, over the past couple of decades, attract immense interest among economics, researchers, and policymakers due to the direct and indirect effect of FDI inflows in the host economy is obvious, therefore ensuring stable flows FDI counties tried to maintain a favorable macroeconomic environment, most prominently stable exchange rate. Several scholars including Froot and Stein (1991), Harris and Ravenscraft (1991), and Osinubi (2010) found a positive association between inflow of FDI and exchange rate movement.

FDI flows in the economy produce spillover effect through employment generation, knowledge sharing, technological transfer, and capital accumulation. In a study, Crespo and Fontoura (2007) explained FDI influence on the economy is evident through labor mobility, backward and forward linkages in the production along with competitiveness. Moreover, the impact of FDI on economic growth is well established and documented in the empirical studies see for an instance, (Gui-Diby, 2014; Iamsiraroj, 2016; Iamsiraroj \& Ulubaşoğlu, 2015).

The effects of foreign direct investment, especially in developing countries, is multifold. As a developing nation Bangladesh persistently looking for FDI inflows over the past decade as it emerged as the key source of long-term capital and assist in domestic capital accumulation as well. The nexus between FDI-led economic growth of Bangladesh attract researchers of exploring their fundamental relationship. In the empirical literature, we observed that the positive effects of FDI on the economic growth of Bangladesh confirmed by different researchers see for an instance, (Bari, 2013; Hussain \& Haque, 2016; Adhikary, 2011; Ahamed \& Tanin, 2010). The growth of FDI inflows in Bangladesh is maintaining at a stable rate of $5.11 \%$ in the year of 2018 from the prior year 2017. In the year of 2017-2018 Bangladesh received FDI of \$506 million from China, \$373 million from the UK, \$191 million from Hong Kong, \$171 million from the US, \$158 million from Singapore, $\$ 135$ from Norway, and \$125 million from South Korea.

Table 1: FDI inflows and investment in Bangladesh

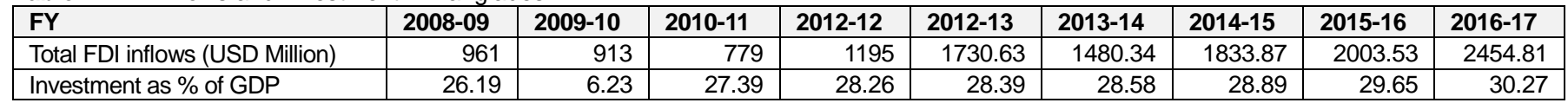

Source: Economic Review of Bangladesh: Ministry of Finance (2016)

The novelty of this study relies on three distinct aspects. First, even though a group of researchers performed empirical studies concentrating on FDI, but their focus is either on FDI impact on economic growth or determinant of FDI inflows in Bangladesh. So far our understanding, there is no such research work carried out investigating the relationship between exchange rate movement and FDI inflows in Bangladesh. With this study, we tried to fill that research gap. Second, in this study, we tried to explore relationship under both symmetric and asymmetric assumptions. The symmetric assumption was tested by applying ARDL bound testing proposed by Pesaran, Shin, and Smith (2001) and the asymmetric relationship was investigated by applying newly proposed Nonlinear ARDL by Shin et al. (2014). ARDL bounds testing approach confirmed the existence of long-run cointegration between FDI and exchange rate. Furthermore, non-linear ARDL confirmed asymmetric effects exist between FDI inflows and exchange rate both in the short - run and long - run, which is applicable in both non-linear ARDL model where both FDI and exchange rate were considered as the dependent variable in the equation.

The remaining section of this paper includes. Section 2 deals with empirical literature reviews. Section 3 contains data and methodology for empirical estimation. Section 4 describes the analysis and interpretation. Section 5 reports the study findings and conclusion.

\section{Theoretical Understanding and Literature Review}

In the 1970s and 1980s, the linkages between FDI and exchange rates emerged as one of the key issues which are investigated in empirical studies see, (Kohlhagen, 1977; Cushman, 1985). With the connection of explaining the relationship between FDI and exchange rates, numbers of theories emerged, however, predominately two theories were considered; proposed by Blonigen (1997) and Froot and Stein (1991). The imperfect capital market, according to Froot and Stein (1991) assumes that the cost of capital accumulation from external sources is higher than raising capital from internal sources. As a result, depreciation of host country currency would create positive motivation for foreign investors with positive effects on their wealth. The imperfect capital market approach, therefore, argued that the exchange rate operates on the wealth effects of FDI. For the reason, a depreciation of the host currency exchange rate increase inflows of FDI.

Over the past decades, the world experienced economic integration through the liberalization of international trade 
by allowing free movement of goods and service (Ahmad \& Harnhirun, 1996) and flows of capital in the form of Foreign Direct Investment (Lipsey et al., 1999) across the country. In particular, FDI is more stable sources of capital flows in developing nations that portfolio investment (Lipsey, Feenstra, Hahn, \& Hatsopoulos, 1999), it assists in expanding production possibilities and through technological slipover (Borensztein \& De Gregorio, 1995). However, researchers put immense interest on explaining FDI-led economic growth hypothesis and a large number of empirical studies, either considering panel data or countryspecific time-series information, confirmed the existence of long-run relationship, see for an instance (Alvarado, Iñiguez, \& Ponce, 2017; Ericsson, 2001; Umoh, Jacob, \& Chuku, 2012). With the same intention, Howitt and Aghion (1998) explained that economic growth directly linked to innovation that is the key outcome from technological advancement in the economy. They also argued that the technology integration process in the economy could accelerate through inflows of FDI and international trade collaboration.

The strong inflows of FDI in the developing economy play a crucial role in achieving sustainable economic growth. It is because FDI increase venture capital for domestic investment, enhance the level of productivity, and technological progress along with managerial expertise in the operation (Pradhan, 2009). In a study, Borensztein, De Gregorio, and Lee (1998) suggested that FDI established a bridge between technology transfer and economic growth. Technological transfer increase efficiency in production through wastage reduction and productivity improvement (Anwar \& Nguyen, 2010). Therefore, FDI treated as an essential vehicle for domestic growth in developing countries (Qamruzzaman, 2015).

FDI inflows are influenced by macroeconomic indicators, especially exchange rate volatility influences at most (Goldberg, 2009). Exchange rate fluctuation affects FDI in two ways. First, the devaluation of host currency reduces the cost of production relative to foreign investors. Second, produce localization of advantages (Phillips \& AhmadiEsfahani, 2008). Empirical studies also advocate FDI inflows can affect money supply in the economy. Finance scholars including Clarke and Ioannidis (1994) and Resende (2008) suggested aggregate money supply in the economy attract foreign investors. In a study, Pain and Van Welsum (2003) argued that the exchange rate impact on the flows of FDI varies across the country with the nature of investment and state of the economy. On the other hand, Harford (2005) explained liquidity position in the economy act as investment key factor of ensuring FDI inflows in the host economy. It is because excess liquidity reduces the cost of capital for investment

In the past couple of decades, several studies had conducted to explore the relationship between exchange rate and inflows of FDI covering country-specific to panel data analysis see, for an instance (Lily, Kogid, Mulok, Thien Sang, \& Asid, 2014; Baek \& Okawa, 2001; Lin, 2011). A study conducted by Boateng, Hua, Nisar, and Wu (2015) to investigate the critical determinants influence on inward FDI in the host country. The study revealed among other macroeconomic variables, exchange rate positively influence on FDI inflows in Norway. A similar type of study performed by Baek and Okawa (2001) to investigate the trend of Japanese FDI inflows in Asia for appreciation and depreciation of Yen against the US dollar and Asian host country currency. The study revealed that appreciation of Yen produces a favorable investment environment for Japanese investor, especially for the export-oriented manufacturing industry.

A study conducted by Liu and Deseatnicov (2016) to investigate the effect of exchange rate policy introduce by the chines government in 2005 on the outward flow of FDI from China. The study revealed an appreciation of RMB negatively influences the outward flow of FDI from China. Theoretically, home currency appreciation positively influences FDI outflows to the host country due to relative wealth effects, future profitability and capital market imperfection (Campa, 1993; Blonigen, 1997). Moreover, Froot and Stein (1991) argued that currency depreciation creates an edge to a foreign investor to acquire domestic asset and control of operation through equity investment. Also, nominal depreciation of exchange rate made export less costly but import costly, which eventually affect on trade balance of the host county. However, a healthy list of empirical studies advocated no effect between the exchange rate and FDI flow, see for an instance (Polat \& Payaslıoğlu, 2016; MacDermott, 2008; Campa \& Goldberg, 1995).

\section{Data and Methodology}

\subsection{Data}

In this study, we employed quarterly data for the period of 1974Q1 to 2016Q4. Data were collected and aggregated from various sources namely, Bangladesh Economic Review published by Ministry of Finance (2016) and statistical yearbook published by Bangladesh Bureau of Statistics (2017), and an annual report published by Bangladesh Bank (2019). Statistical package EViews9 EViews9.5 (2017) used for econometric analysis.

Foreign direct investment is measured by the net inflows of investment in acquiring the listing management in an enterprise operating in the economy. Foreign direct investment, generally, includes merger and acquisition, building new facilities, reinvestment of profits earning from overseas operation, and intercompany loan (Belloumi, 2014).

The demand for FDI inflows in the economy is also influenced by aggregated economic behavior along with the exchange rate. An aggregate economy like the expansionary or contractionary economic policy also influences in order to address the aggregated economic effect in the equation by 
following Bahmani-Oskooee, Halicioglu, and Mohammadian (2018) and Bahmani-Oskooee and Mohammadian (2016). We also included two proxy variables in the equation namely; first, monetary policy refers to real broad money supply per capita in total and second, fiscal policy, refers to consolidated government expenditures per capita in total. Nominal figures are deflated by GDP deflator, respectively. Based on research variables the generalized form of the empirical model can be represented in the following manner:

$F D I=\int E X, M, G$

After transformation into a linear form, equation (1) can be represented in the following way:

$\ln F D I_{t}=\alpha_{0}+\beta_{1} \ln E X_{t}+\beta_{2} \ln M_{t}+\beta_{3} \ln G_{t}+\epsilon_{t}$

Where $E X$ is the exchange rate, FDI denotes the foreign direct investment, $M$ represents money supply, and $G$ is the real government expenditure. Model coefficients of $\beta_{1}$ to $\beta_{3}$ in equation (2) represent long-run elasticities, and $\epsilon_{t}$ stands for error correction term the equations.

\subsection{RDL Bound Testing for Long-run Cointegration}

This study employs the ARDL bound testing approach of determining long-run association over the existing traditional cointegration test due to the following benefits: First, ARDL can perform cointegration estimation regardless of sample size, it is implying that with small and finite sample size consist of 30 to 80 observations ARDL is capable to estimate the model with efficiency and consistency (Ghatak \& Siddiki, 2001). Second, this approach is suitable in a mixed order of variables' integration, as such when few variables are stationary at a level $\mathrm{I}(0)$ and few become stationary after first difference I(1). Third, ARDL estimation with appropriate optimal lag can correct the problem of serial correlation and the indignity problem in the equation (Pesaran et al., 2001). Fourth, the ARDL simultaneously can examine both longrun and short-run cointegration by providing unbiased estimators (Pesaran et al., 2001).

Accepting the underlying benefits of ARDL bound testing approach in examining the long run association between foreign direct investment, exchange rate, monetary policy, and fiscal policy, we apply ARDL bound testing procedure, initially proposed by Pesaran and Shin (1998) and later extension was done by Pesaran et al. (2001) and Narayan (2004) within an Autoregressive Distributed lag framework (ARDL). To perform Bound testing, it is imperative to model equation (2) as a conditional ARDL as follows (3a, 3b, 3c, and 3d), where each variable treated as a dependent variable so that best-fitted model can estimate in further:

$$
\begin{aligned}
& \Delta \operatorname{lnFDI} I_{t}=\alpha_{0}+\sum_{i=1}^{n} \mu_{11} \Delta \ln F D I_{t-i}+\sum_{i=0}^{n} \mu_{12} \Delta \ln E X_{t-i}+\sum_{i=0}^{n} \mu_{13} \Delta \ln M_{t-i}+\sum_{i=0}^{n} \mu_{14} \Delta \ln G_{t}+\gamma_{11} \ln F D I_{t-1}+\gamma_{12} \ln E X_{t-1}+\gamma_{13} \ln M_{t-1} \\
& +\gamma_{14} \ln G_{t-1}+\omega_{1 t} \\
& \Delta \ln E X_{t}=\alpha_{0}+\sum_{i=0}^{n} \mu_{21} \Delta \ln F D I_{t-i}+\sum_{i=1}^{n} \mu_{22} \Delta \ln E X_{t-i}+\sum_{i=0}^{n} \mu_{23} \Delta \ln M_{t-i}+\sum_{i=0}^{n} \mu_{24} \Delta \ln G_{t}+\gamma_{21} \ln F D I_{t-1}+\gamma_{22} \ln E X_{t-1}+\gamma_{23} \ln M_{t-1} \\
& +\gamma_{24} \ln G_{t-1}+\omega_{2 t} \\
& \Delta \ln M_{t}=\alpha_{0}+\sum_{i=0}^{n} \mu_{31} \Delta \ln F D I_{t-i}+\sum_{i=0}^{n} \mu_{32} \Delta \ln E X_{t-i}+\sum_{i=1}^{n} \mu_{33} \Delta \ln M_{t-i}+\sum_{i=0}^{n} \mu_{34} \Delta \ln G_{t}+\gamma_{31} \ln F D I_{t-1}+\gamma_{32} \ln E X_{t-1}+\gamma_{33} \ln M_{t-1} \\
& +\gamma_{34} \ln G_{t-1}+\omega_{3 t} \\
& \Delta \ln G_{t}=\alpha_{0}+\sum_{i=0}^{n} \mu_{41} \Delta \ln F D I_{t-i}+\sum_{i=0}^{n} \mu_{42} \Delta \ln E X_{t-i}+\sum_{i=0}^{n} \mu_{43} \Delta \ln M_{t-i}+\sum_{i=1}^{n} \mu_{44} \Delta \ln G_{t}+\gamma_{41} \ln F D I_{t-1}+\gamma_{42} \ln E X_{t-1}+\gamma_{43} \ln M_{t-1} \\
& +\gamma_{44} \ln G_{t-1}+\omega_{4 t}
\end{aligned}
$$

Where $\Delta$ is the first difference operator, $\mu_{11}$ to $\mu_{44}$ represents short-run elasticity, $\gamma_{11}$ to $\gamma_{44}$ for long-run coefficients, and $\omega_{t}$ is the error correction term. The bound test for ascertaining the long-run co-integration can be conducted by using F-statistics. The critical value of Fstatistics will be extracted from Pesaran et al. (2001) and Narayan (2004) of getting stronger evidence in favor for the existence of long-run association see, (Muhammad Adnan Hye, 2011). The null hypothesis of long-run co-integration in equation 3(a) to 3(4) as follows:

$$
H_{0}:\left[\begin{array}{l}
\gamma_{11}=\gamma_{12}=\gamma_{13}=\gamma_{14} \\
\gamma_{21}=\gamma_{22}=\gamma_{23}=\gamma_{24} \\
\gamma_{31}=\gamma_{32}=\gamma_{33}=\gamma_{34} \\
\gamma_{41}=\gamma_{32}=\gamma_{33}=\gamma_{44}
\end{array}\right]=0
$$


About decision making, whether the long-run cointegration exists or not, Pesaran et al. (2001) provide the following guidelines:

[1]. Long-run cointegration confirmed if the calculated F-statistics is higher than the upper bound of the critical value

[2]. No long-run cointegration confirmed if the calculated F-statistics is lower than lower bound of the critical value
[3] If the F-statistics value lies between upper bound and lowers bound then conclusive decision might not reach regarding long-run association among variables

Once, long-run cointegration ascertains using earlier ARDL equation ( $3 a, 3 b, 3 c$, and $3 d$ ), the next two steps to determine long-run elasticity and short-run elasticities. The long-run ARDL (m, n, o, and p) equilibrium can be presented as follows:

$$
\Delta \operatorname{lnFDI_{t}}=\alpha_{0}+\sum_{k=1}^{m} \mu_{k} \ln F D I_{t-k}+\sum_{k=0}^{n} \mu_{k} \ln E X_{t-k}+\sum_{k=0}^{o} \mu_{k} \ln M_{t-k}+\sum_{k=0}^{p} \mu_{k 4} \ln G_{t}+\omega_{1 t}
$$

The appropriate lag length will be estimated by considering AIC. Empirical estimation with time-series data, Pesaran et al. (2001) suggests optimal lag length is 2 . The short-run elasticities can be derived by formulating error correction model as follows:

$$
\Delta \operatorname{lnFDI_{t}}=\alpha_{0}+\sum_{k=1}^{m} \mu_{k} \Delta \ln F D I_{t-k}+\sum_{k=0}^{n} \mu_{k} \Delta \ln E X_{t-k}+\sum_{k=0}^{o} \mu_{k} \Delta \ln M_{t-k}+\sum_{k=0}^{p} \mu_{k 4} \Delta \ln G_{t}+\emptyset E C T_{t-k}+\omega_{1 t}
$$

where the error correction term can be expressed:

$$
E C T_{t}=\Delta l n F D I_{t}-\alpha_{0}-\sum_{k=1}^{m} \mu_{k} \Delta l n F D I_{t-k}-\sum_{k=0}^{n} \mu_{k} \Delta \ln E X_{t-k}-\sum_{k=0}^{o} \mu_{k} \Delta \ln M_{t-k}-\sum_{k=0}^{p} \mu_{k 4} \Delta \ln G_{t}+\omega_{1 t}
$$

\subsection{Nonlinear ARDL Approach}

The original assumption behind in equation ( $3 \mathrm{a}$ and $3 \mathrm{~b}$ ) is the asymmetric relationship between foreign direct investment (FDI) and Exchange rate (EX). Considering the exchange rate effect on FDI inflows in the economy, empirical literates suggest that depreciation of the home currency exchange rate attract foreign long-term investment in the form of FDI. On the other hand, in developing the economy, FDI considered as a prime source of foreign currency received and holding a substantial amount of foreign currency helps the home economy to appreciate exchange rate and maintain stability as well. How valid the assumption is? To validate the assumption of the symmetric or asymmetric effects of Exchange rate on FDI inflows and FDI effects on Exchange rate, we follow the newly developed nonlinear cointegration model proposed by Shin et al. (2014) and separate appreciation and depreciation of FDI and exchange rate in their respective empirical investigation.

Nonlinear ARDL, according to Ali, Shan, Wang, and Amin (2018), possesses certain advantages over existing investigation methodologies ( e.g., Error correction model, the smoothing ECM, and the threshold ECM) to jointly test dynamic cointegration and asymmetries in the underly variables. Furthermore, NARDL provides a model flexible framework by relaxing the restriction of the variable same order of integration, which holds true for ECM (Katrakilidis \& Trachanas, 2012). In addition, NARDL estimation allows differentiating between the linear and nonlinear cointegration. Like standard ARDL and other traditional cointegration test assume symmetric effects from the independent variable to the dependent variable (Fousekis, Katrakilidis, \& Trachanas, 2016). Furthermore, Arize, Malindretos, and Igwe (2017) pointed out that NARDL is more efficient in the estimation of the short-run and longrun coefficient by allowing long-run dynamics and distributed lagged in a single common cointegration victor.

We decompose the appreciation of TK against USD denoted by $\Delta \ln \mathrm{EX}^{+}$and depreciation of TK against USD represented by $\Delta \ln \mathrm{EX}^{-}$. On the other hand, positive change in FDI changes $\Delta \operatorname{lnFDI}{ }^{+}$and negative change in FDI denoted by $\Delta \mathrm{lnFDI}^{-}$respectively. Using new notation, we create two sets of new time series data based on positive (POS) and negative (NEG) of the exchange rate. Series can be derived using the following equations: 


$$
\begin{aligned}
& \left\{\begin{array}{l}
P O S(E X)_{t}=\sum_{k=1}^{t} \ln E X_{k}^{+}=\sum_{K=1}^{T} M A X\left(\Delta \ln E X_{k}, 0\right) \\
N E G(E X)_{t}=\sum_{k=1}^{t} \ln E X_{k}^{-}=\sum_{K=1}^{T} M I N\left(\Delta \ln E X_{k}, 0\right)
\end{array}\right. \\
& \left\{\begin{array}{l}
P O S(F D I)_{t}=\sum_{k=1}^{t} \ln F D I_{k}^{+}=\sum_{K=1}^{T} M A X\left(\Delta \ln F D I_{k}, 0\right) \\
N E G(F D I)_{t}=\sum_{k=1}^{t} \ln F D I_{k}^{-}=\sum_{K=1}^{T} M I N\left(\Delta \ln F D I_{k}, 0\right)
\end{array}\right.
\end{aligned}
$$

Next step to replace positive and negative series of the exchange rate in equation (3a) and positive-negative change in equation (3b).Once inserted, the new error correction equation arrives as follows:

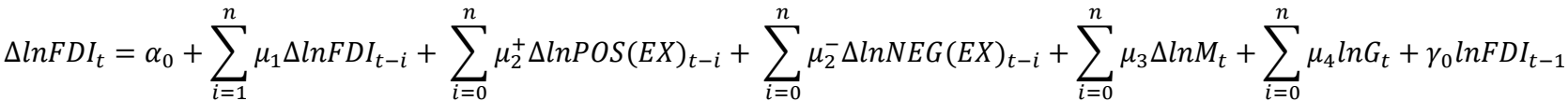

$$
\begin{aligned}
& +\gamma_{1}^{+} \ln P O S(E X)_{t-1}+\gamma_{1}^{-} \ln N E G(E X)_{t-1}+\gamma_{2} \ln M_{t-1}+\gamma_{3} \ln G_{t-1}+\omega_{t} \\
& \Delta \ln E X_{t}=\alpha_{0}+\sum_{i=1}^{n} \beta_{1} \Delta \ln E X_{t-i}+\sum_{i=0}^{n} \beta_{2}^{+} \Delta \ln P O S(F D I)_{t-i}+\sum_{i=0}^{n} \beta_{2}^{-} \Delta \ln N E G(F D I)_{t-i}+\sum_{i=0}^{n} \beta_{3} \Delta \ln M_{t}+\sum_{i=0}^{n} \beta_{4} \ln G_{t}+\pi_{0} \ln E X_{t-1} \\
& +\pi_{1}^{+} \ln P O S(F D I)_{t-1}+\pi_{1}^{-} \ln N E G(F D I)_{t-1}+\pi_{2} \ln M_{t-1}+\pi_{3} \ln G_{t-1}+\omega_{t}
\end{aligned}
$$

In the opinion of Shin et al. (2014), the approach of bound testing proposed by Pesaran et al. (2001) is also applicable to equation (9, and 10) for ascertaining long-run cointegration. Since, in model construction, we incorporate two additional series of nonlinearity in the adjustment process, therefore, it is widely known as nonlinear ARDL and equation (3a, 3b, 3c, and 3d) know as linear ARDL. Estimation of nonlinear ARDL model evaluated under four assessment. First, short-run asymmetry be established if $\mu_{2}^{+} \neq \mu$ for the exchange rate and $\pi_{2}^{+} \neq \pi_{2}^{-}$for FDI. Second, short-run impact asymmetry confirm, if $\sum \mu_{2}^{+} \neq$ $\sum \mu_{2}^{-}$for the exchange rate and $\sum \pi_{2}^{+} \neq \sum \pi_{2}^{-}$for FDI. Third, long run asymmetry ascertain, if $\gamma_{1}^{+} \neq \gamma_{1}^{-}$for the exchange rate and $\beta_{2}^{+} \neq \beta_{2}^{-}$for FDI.

Once, equation $(9 \& 10)$ is estimated then we can make a decision, whether the impact of exchange rate on FDI is symmetrical or asymmetric. If the coefficient of both positive and negative changes carry the same size and sign, it confirms symmetric otherwise asymmetric. In the next section, we estimate both symmetric linear ARDL using equation ( $3 \mathrm{a}, 3 \mathrm{~b}, 3 \mathrm{c}$, and $3 \mathrm{~d}$ ) and asymmetric ARDL using equation $(9 \& 10)$.

\subsection{Granger-Casualty Test}

In order to ascertain directional causality both in the short-run and in the long run, in study performs Grangercasualty test under error correction term. The causality among variables can be examined by using the following equation, where each variable treated as a dependent variable.

$$
\left[\begin{array}{c}
\Delta l n F D I_{t} \\
\Delta \ln E X_{t} \\
\Delta \ln M_{t} \\
\Delta \ln G_{t}
\end{array}\right]=\left[\begin{array}{c}
\alpha_{11} \\
\alpha_{21} \\
\alpha_{31} \\
\alpha_{41}
\end{array}\right]+\left[\begin{array}{c}
\ln F D I_{t-1} \\
\ln E X_{t-1} \\
\ln M_{t-1} \\
\ln G_{t-1}
\end{array}\right]\left[\begin{array}{l}
\beta_{11} \beta_{12} \beta_{13} \beta_{14} \\
\beta_{21} \beta_{22} \beta_{23} \beta_{24} \\
\beta_{31} \beta_{32} \beta_{33} \beta_{34} \\
\beta_{41} \beta_{42} \beta_{43} \beta_{44}
\end{array}\right]+\sum_{s=1}^{q}\left[\begin{array}{l}
\gamma_{11} \gamma_{12} \gamma_{13} \gamma_{14} \\
\gamma_{21} \gamma_{22} \gamma_{23} \gamma_{24} \\
\gamma_{31} \gamma_{32} \gamma_{33} \gamma_{34} \\
\gamma_{41} \gamma_{42} \gamma_{43} \gamma_{44}
\end{array}\right]\left[\begin{array}{c}
\Delta \ln F D I_{t-s} \\
\Delta \ln E X_{t-s} \\
\Delta \ln M_{t-s} \\
\Delta \ln G_{t-s}
\end{array}\right]+\left[\begin{array}{c}
\vartheta_{1} \\
\vartheta_{2} \\
\theta_{3} \\
\vartheta_{4}
\end{array}\right] E C T_{t}+\left[\begin{array}{c}
\varphi_{1 t} \\
\varphi_{2 t} \\
\varphi_{3 t} \\
\varphi_{4 t}
\end{array}\right]
$$

\section{Results}

\subsection{Unit Root Test}

While investigating long-run cointegration through
ARDL approach, determination of variables' order of integration is not essential. Empirical studies, however, including Ouattara (2006), suggest the presence of secondorder cointegration invalid estimated F-statistic for evaluation. To confirm the nonexistence of second-order integration of any variables, we purposively use ADF unit root test proposed by Dickey and Fuller (1979), P-P unit root 
test proposed by Phillips and Perron (1988), and KPSS unit root test proposed by Kwiatkowski, Phillips, Schmidt, and Shin (1992). Unit root estimation reports in Table 3. The stationary test confirms none of the research variables are integrated after the second difference, which induces us to move further for symmetric and asymmetric estimation between FDI and exchange rate.

Table 2: Unit root test estimation

\begin{tabular}{|c|c|c|c|c|c|c|c|c|c|}
\hline 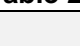 & \multicolumn{3}{|c|}{ ADF } & \multicolumn{3}{|c|}{ P-P } & \multicolumn{3}{|c|}{ KPSS } \\
\hline & At level & $\Delta$ & I & At level & $\Delta$ & I & At level & $\Delta$ & I \\
\hline InFDI & $-3.69^{\star \star}$ & - & $I(0)$ & $-3.69^{\star *}$ & - & $\mathrm{I}(0)$ & 0.11 & $0.35^{\star *}$ & $I(1)$ \\
\hline $\ln \mathrm{G}$ & -2.39 & $-3.98^{* *}$ & $\mathrm{I}(1)$ & $-1.98^{*}$ & $-4.60^{\star \star *}$ & $I(1)$ & 0.09 & $0.22^{\star *}$ & $\mathrm{I}(1)$ \\
\hline $\ln M$ & -3.46 & $-5.26^{\star \star \star}$ & $\mathrm{I}(1)$ & $-6.51^{\star * *}$ & - & $\mathrm{I}(0)$ & 0.10 & $0.18^{* *}$ & $\mathrm{I}(1)$ \\
\hline
\end{tabular}

Note 1. FDI for Foreign Direct Investment, EX for Exchange rate against US \$, G for Gross Capital Formation, and M for money supply in the economy (M3).

Note 2. $\Delta$ denotes first difference operator, I for an order of integration.

Note 3. ADF for augmented Dickey-Fuller test, P-P for Phillip-Perron and KPSS for Kwiatkowski-Phillips- Schmidt-Shin test

Note $4 .{ }^{* * * / * *}$ indicate significance at $1 \%$ and $5 \%$ levels, respectively.

\subsection{Linear ARDL Estimation}

In the previous section, we observed that variables show the different order of integration, under this situation best cointegration test can be performed using ARDL bound testing. In this section, we proceed to estimate ARDL estimation based on symmetric effect assumption between exchange rate and FDI inflows applying linear ARDL bound testing approach proposed by Pesaran et al. (2001) and Narayan and Narayan (2005) by following pre-specified model equation ( $3 \mathrm{a}$ to $3 \mathrm{~d}$ ). Table 3 reports full information of estimation with four (04) Panel output.

Table 3: Linear ARDL Bound testing

\begin{tabular}{|c|c|c|c|c|c|}
\hline & & & & & \\
\hline \multicolumn{4}{|c|}{ Panel-A: Long-run cointegration estimation } & F-statistics & Co-integration \\
\hline \multicolumn{2}{|c|}{$F(\ln E X)=(\ln E X / \ln F D I, \ln G, \ln M)$} & \multicolumn{2}{|c|}{$-E q(3 b)$} & $7.59^{\star \star \star}$ & Presence \\
\hline \multicolumn{4}{|c|}{$F(\ln M)=(\ln M / \ln E X, \ln G, \ln F D I)$} & 4.01 & Absent \\
\hline \multicolumn{3}{|c|}{ Critical value at $1 \%$ level of significance } & $\mathrm{K}$ & $\mathrm{I}(0)$ & $\mathrm{I}(1)$ \\
\hline \multicolumn{3}{|c|}{ Pesaran et al. (2001) } & 3 & 4.29 & 5.61 \\
\hline \multicolumn{6}{|c|}{ Panel B: Long-run estimation } \\
\hline \multicolumn{3}{|c|}{ InFDI as dependent variable } & \multicolumn{3}{|c|}{ InEX as dependent variable } \\
\hline Variables & coefficients & t-statistics & Variables & coefficients & t-statistics \\
\hline $\operatorname{lnEX}$ & $-0.965^{\star \star}$ & 0.784 & InFDI & $-2.462^{* \star}$ & -0.366 \\
\hline InM & $0.157^{\star *}$ & 0.711 & $\ln M$ & $0.277^{\star \star}$ & 0.764 \\
\hline $\ln G$ & $-0.417^{*}$ & -0.681 & InGCF & 3.085 & 3.223 \\
\hline$\Delta \operatorname{lnEX}$ & $-0.27^{\star \star}$ & -3.747 & $\Delta \mathrm{InFDI}$ & $2.522^{\star \star}$ & 3.462 \\
\hline$\Delta \operatorname{lnM}$ & $-0.029^{*}$ & -3.689 & $\Delta \operatorname{lnM}$ & $0.281^{* *}$ & 3.627 \\
\hline$\Delta \ln G$ & -0.004 & -0.695 & $\Delta \mathrm{lnGCF}$ & $0.947^{*}$ & 5.632 \\
\hline \multicolumn{6}{|c|}{ Panel - D: Residual Diagnostic test } \\
\hline$R^{2}$ & 0.891 & & & 0.841 & \\
\hline$\delta$ & 0.811 & & & 0.762 & \\
\hline$F_{\text {statistics }}^{2}$ & $31.12^{\star *}$ & & & $25.18^{\star \star}$ & \\
\hline$x_{\text {Autocorrelation }}^{2}$ & $1.80(0.18)$ & & & $0.13(0.87)$ & \\
\hline$x_{\text {Heteroskedasticity }}^{2}$ & $079(0.59)$ & & & $1.15(0.25)$ & \\
\hline$x_{\text {Normality }}^{2}$ & $2.032(0.36)$ & & & $5.161(0.12)$ & \\
\hline$x_{R E S E T}^{2}$ & $0.97(0.33)$ & & & $1.807(0.12)$ & \\
\hline
\end{tabular}


Table 3 (panel - A) reports F-statistics of various ARDL estimation along with the two critical value extracted from Pesaran et al. (2001) as well as Narayan (2005) which are quoted for small samples by following Bildirici and Ozaksoy (2017). It is observed from ARDL bound testing where each variable serves as the dependent variable in the equation. The study found F-statistics when FDI, EX, and $\mathrm{M}$ considered as dependent variables $\quad[\quad F(\ln F D I)=(\ln F D I / \ln E X, \ln G, \ln M)=$ 9.53], $F(\ln E X)=(\ln E X / \ln F D I, \ln G, \ln M)=7.53$, and $F(\ln G)=(\ln G / \ln E X, \ln F D I, \ln M)=9.80$ are higher than the upper bound of critical value at $1 \%$ level of significance $(\mathrm{PCV}=5.61$ and $\mathrm{NCV}=5.41)$. This is suggesting that the null hypothesis that is "no cointegration" cannot be accepted; rather we accept the existence of long-run cointegration between exchange rate, FDI inflows, monetary policy, and fiscal policy of Bangladesh. In particular, Study findings suggest exchange rate movement and FDI flows move together, which is supported by empirical studies by Lily et al. (2014).

Table 3 (Panel -B) reports long-run estimation for both models, where FDI and exchange rate serves as dependent variables in their respective equations. When FDI is treated as the dependent variable, the study found that the real exchange rate against the USD positively influences the FDI inflows in Bangladesh in the long run. It is implying that the real depreciation of the exchange rate boost inflows of FDI.

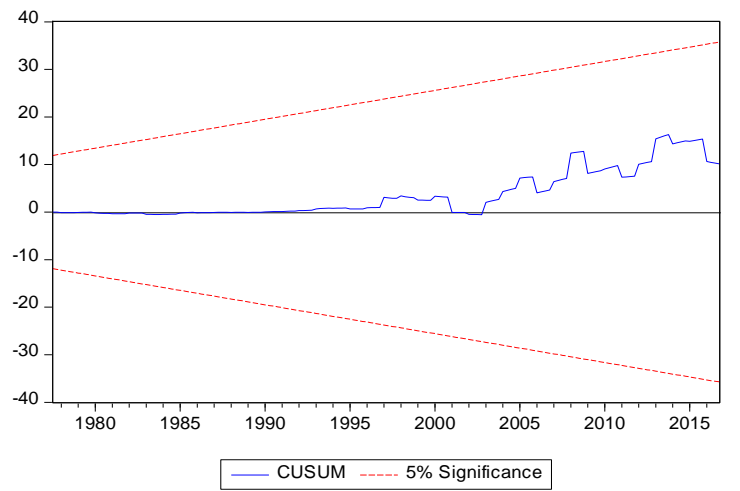

Fig 1 CUSUM test for Model stability with FDI as Dependent Variable

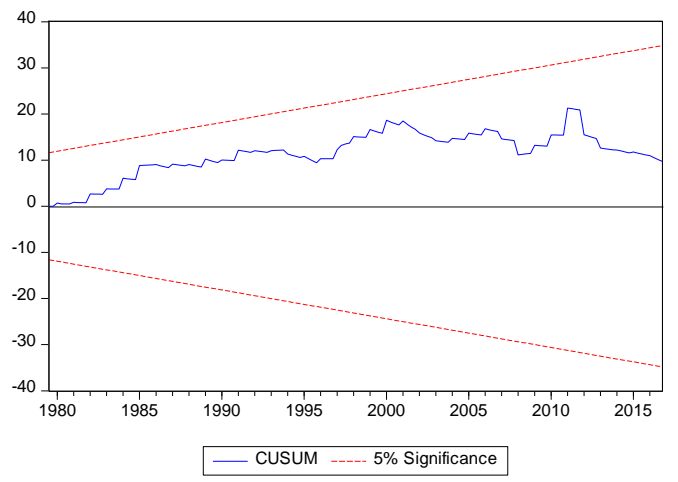

Fig 3 CUSUM test for model stability with Exchang rate as Dependent Variable
Findings are supported by empirical studied such as Froot and Stein (1991), Dees (1998), and Ang (2008).

Table 3 (Panel - C) exhibits short-run estimation. The short-run association specify the lagged error correction term $E C T_{t-1}$. We found the error correction term is negative and statistically significant (at 1\%) in both cases, which confirm the existence of a short-run relationship between exchange rate and FDI inflows. The coefficients of both model $\left(E C T_{t-1 E X}=-0.96, E C T_{t-1 F D I}=-0.79\right)$ indicate the high speed of adjustment towards long-run equilibrium with prior year shock in the exchange rate and FDI.

We also perform four residual diagnostic tests, see Table 3 (Panel - D), to confirm model construct validation and robustness in estimation as suggested by Pesaran et al. (2001). Test of autocorrelation confirms that the estimated model is free from serial correlation, and test of normality ensure a normal distribution of error terms in the equation. We also observed that the statistics of Ramsey's RESET test confirm the correctness of model specification. Finally, to ensure estimation of long-run and short-run coefficient stability, by following Pesaran et al. (2001), we perform residual-based CUSUM and CUSUMSQ test, confirming that the estimating parameters are stable as lines between critical boundaries at a 5\% level of significant (see Figure 1).

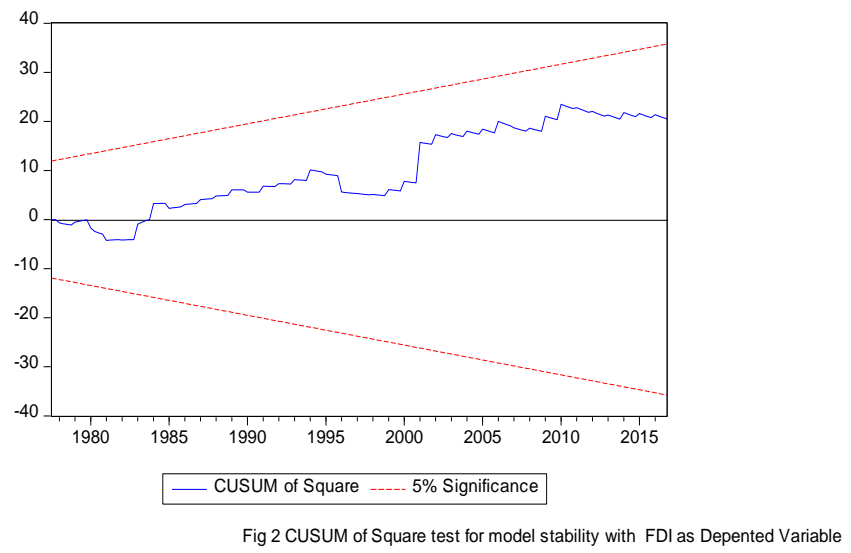

Figure 1: Residual-based CUSUM and CUSUMSQ test

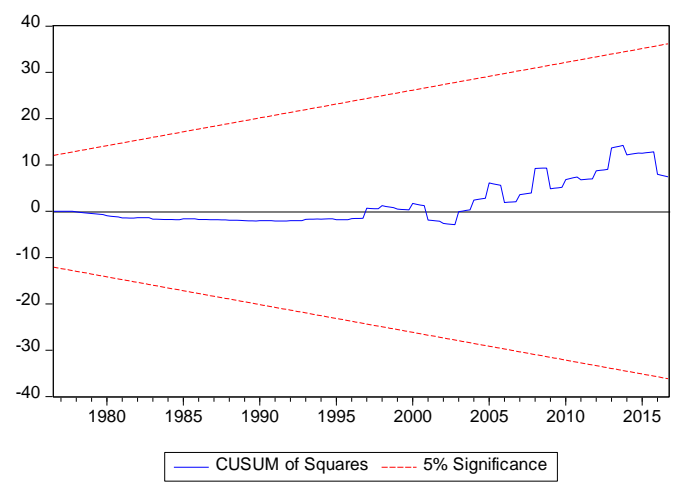

Fig 4 CUSUM of Square test from model stabiity with exchange rate as Dependent Variable 


\subsection{Nonlinearity Estimation for the Period 1974Q1-2016Q4}

The previous section provides evidence of a linear relationship between the exchange rate and the inflows of FDI. Findings are consistent with theoretical and empirical studies. Now, we move towards examining the existence of asymmetric relationship by applying newly nonlinear ARDL approach proposed by Shin et al. (2014) following model (9) and (10). Table 4 reports full information on asymmetric estimation. To ascertain robustness and stability in the model estimation, we performed several residual-based

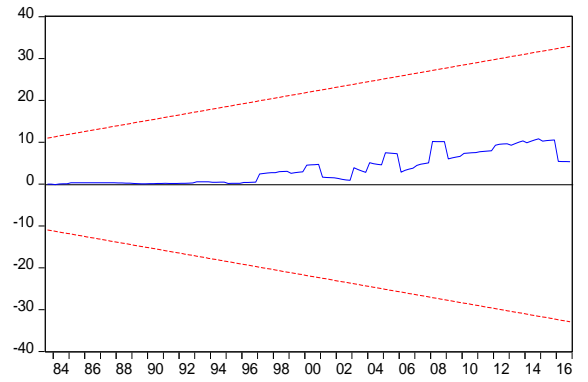

— CUSUM ---. $5 \%$ Significance

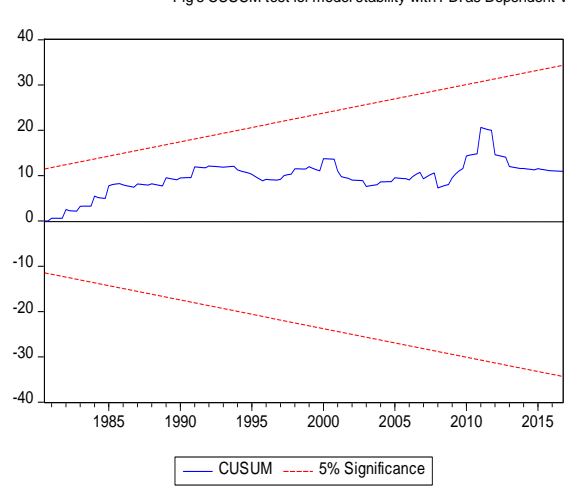

Fig 7 CUSUM test for model stability with Exchange rate as Dependent variable (Asymmetric ARDL) diagnostics tests see, Table 4 (panel-D), as suggested by empirical studies. It is seen from a residual test, that model is free from serial correlation, error terms normally distributed and no problem of homoscedasticity. Moreover, The Ramsey's RESET confirms model construction validity as well. Model estimation stability investigated by applying residual recursive test proposed by Pesaran et al. (2001), commonly known as CUSUM and CUSUM of the square, ascertaining the model stability in estimation as the parameters fall within the critical value at a $5 \%$ level of significance (Figure 2).
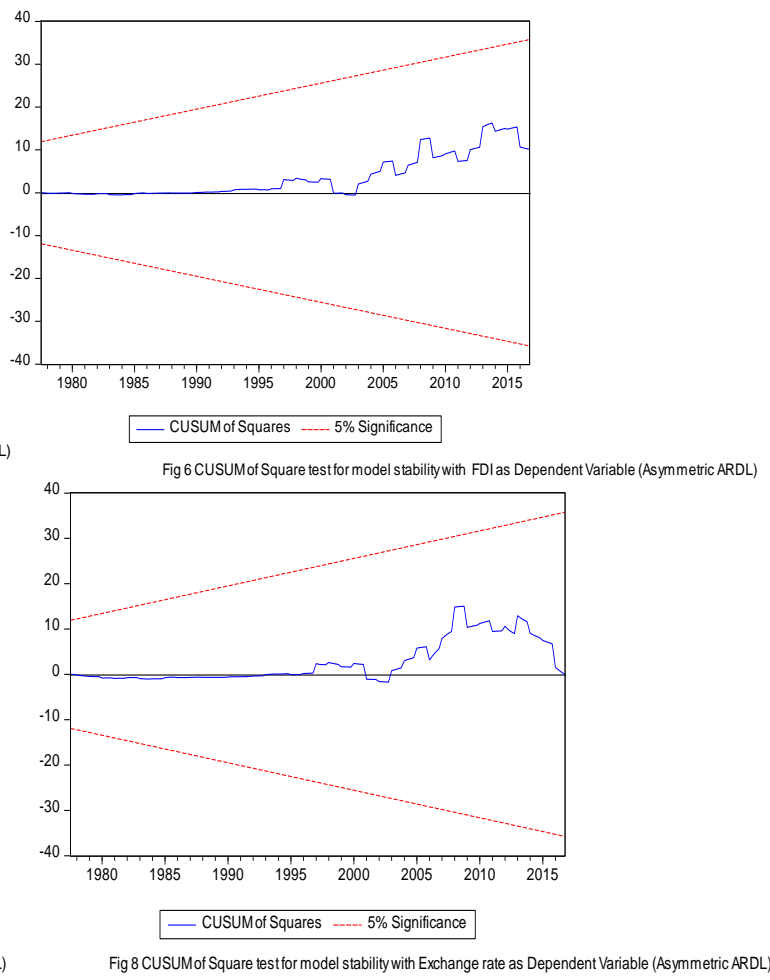

Figure 2: CUSUM and CUSUM of the square

Now we proceed to estimate the existence of cointegration test, in particular, joint cointegration test in both nonlinear equation 9 and 10 . We found test statistics of $F(f d i)_{p s s}=19.25$ and $F(e x)_{p s s}=11.84$ is higher than the upper bound of critical value ${ }^{4}$ at $1 \%$ level of significance. So we can conclude in favor of asymmetric long-run association between examined variables. It is also observed that the coefficients' error correction term $\left(E C T_{t-1}\right)$ in case of both tested model is negative and statistically significant at $1 \%$ level of significance. It supports the previous confirmation of long run cointegration. The coefficients of error correction term -0.39 in case of FDI as the dependent variable and -0.625 in case of

4 Following Shin et al. (2011), we adopted a conservative approach to the choice of critical values and employed $\mathrm{k}=1$. the exchange rate as the dependent variable in the model estimation, which is negative and statistically significant at a $1 \%$ level of significance. The error correction term explained that any shock in the short run could be absorbed and reach the long run equilibrium at a speed of $39 \%$ and $62 \%$ per quarter.

We performed a standard Wald test to investigate the symmetric relationship. In Table 4 (panel-C), $W_{L R}$ indicates a Wald test with null hypothesis symmetric relationship $\left(L_{E X}^{+}=L_{E X}^{-}\right.$and $\left.L_{F D I}^{+}=L_{F D I}^{-}\right)$. The null hypothesis of the short-run symmetric relation $W_{S R}\left(S_{E X}^{+}\right.$ $=S_{E X}^{-}$and $S_{F D I}^{+}=S_{F D I}^{-}$). For the long run, the null hypothesis of symmetric relation is rejected at $1 \%$ level of significance. More particularly, we found $W_{L R(f d i)}=$ $9.312(p-0.0079)$ of model (9), and $W_{L R(f d i)}=$ $8.88(p-0.0025)$ for the model (10). For the short-run 
symmetric test, we found for the model (9) $W_{S R(F D I)}=$ $15.14(p-0.001)$ and for the model (10) $W_{S R(E X)}=$ $12.19(p-0.0079)$, respectively. Results of both model (9) $\&$ (10) suggest rejection of the null hypothesis. So one can conclude, there is an asymmetric relationship in the shortrun as well.

The study confirms the existence of an asymmetric relationship between FDI inflows and exchange rate of the host country. With this, we move to assess the impact of positive and negative changes in FDI flows and exchange rate in both models (9) and (10). In Table 4, for the model (9), we observed that the positive shock in Exchange rate $\mathrm{EX}^{+}$negatively associated and negative shock in Exchange rate EX-positively associated with inflows of foreign direct investment in Bangladesh. On the other hand, both coefficients of positive and negative shock in the exchange rate are statistically significant at $1 \%$ level of significance. Study finding suggests that with $1 \%$ appreciation in Exchange rate results decreases in FDI flows by $1.81 \%$. Furthermore, $1 \%$ depreciation in the real exchange rate also decreases FDI inflows by $7.68 \%$. The magnetite of the negative component of the Exchange rate is significantly higher, therefore, maintaining a stable exchange rate is desirable in order to attract foreign investors, because investor always prefers stable future earrings form their investment. In the short run, we observed that both positive and negative shocks in the exchange rate have negatively linked inflows of FDI, it is implying that a $1 \%$ appreciation in the exchange rate will cause a reduction of FDI inflows in Bangladesh by $0.125 \%$ and $1 \%$ depreciation in the exchange rate will accelerate FDI inflows by $0.723 \%$.

For model (10), when the exchange rate serves as a dependent variable, study findings disclosed that both positive and negative shocks in FDI positively associated with exchange rate determination. For an instant, a $1 \%$ increase in FDI flow can appreciate the exchange rate by $0.62 \%$, on the other hand, the reduction of FDI flows can depreciate the exchange rate by $0.86 \%$, respectively. In short-run estimation, $1 \%$ of additional inflows of FDI in Bangladesh can strengthen the currency conversion rate by $0.422 \%$ and $1 \%$ downtrend of FDI can cause depreciation of the exchange rate by $0.034 \%$. The magnitude of FDI inflows' variation in the short run is significant in the case of exchange rate appreciation. Our Study findings suggest that receiving a substantial amount of FDI allows Bangladesh to maintain a level of the foreign reserve at optimal, therefore additional receipt of FDI assists in strengthening currency conversion against USD and appreciates TK eventually.

Table 4: Dynamic Asymmetric Estimation exchange rate and FDI nexus

\begin{tabular}{|c|c|c|c|c|c|}
\hline & coefficients & Std. Error & & coefficients & Std. Error \\
\hline \multicolumn{3}{|c|}{ Model 1 FDI as Dependent Variable } & \multicolumn{3}{|c|}{ Model 2 Exchange rate as dependent variable } \\
\hline \multicolumn{6}{|c|}{ Panel -A: Long-run estimation } \\
\hline $\mathrm{C}$ & -43.298 & 12.939 & $\mathrm{C}$ & $-1.054^{\star \star \star}$ & 0.802 \\
\hline $\operatorname{lnFDI}(-1)$ & $-1.162^{\star \star \star}$ & 0.213 & $\ln E X(-1)$ & $-0.644^{\star *}$ & 0.036 \\
\hline $\ln E X^{+}$ & $-1.81^{\star \star *}$ & 2.761 & $\Delta \ln F D I^{+}$ & $0.628^{\star * \star}$ & 0.423 \\
\hline $\ln E X^{-}$ & $7.68^{\star \star \star}$ & 9.428 & $\Delta \ln F D I^{-}$ & $0.086^{\star *}$ & 0.76 \\
\hline $\operatorname{lnM}$ & $0.591^{\star \star *}$ & 1.559 & $\ln M$ & $0.054^{*}$ & 0.048 \\
\hline $\ln G$ & $1.275^{\star \star}$ & 4.519 & $\ln G$ & $0.139^{\star \star \star}$ & 0.079 \\
\hline \multicolumn{6}{|c|}{ Panel - B: Short-run estimation } \\
\hline $\operatorname{lnFDI}(-1)$ & $14.233^{\star *}$ & 2.228 & $\Delta \operatorname{lnEX}(-1)$ & $0.256^{\star * *}$ & 0.08 \\
\hline $\ln E X^{+}$ & $-0.125^{\star \star \star}$ & 2.195 & $\Delta \ln F D I^{+}$ & $0.422^{* \star *}$ & 0.085 \\
\hline $\ln E X^{-}$ & $-0.723^{\star *}$ & 3.024 & $\Delta \ln F D I^{-}$ & $0.034^{\star *}$ & 1.21 \\
\hline $\operatorname{lnM}$ & $-0.183^{\star *}$ & 0.122 & $\Delta \operatorname{lnM}$ & $-0.067^{\star * \star}$ & 0.082 \\
\hline $\ln G$ & $-12.14^{\star * *}$ & 3.784 & $\Delta \operatorname{lnG}$ & $-0.067^{\star \star}$ & 0.082 \\
\hline$E C M_{t-1}$ & $-0.392^{\star * * *}$ & & $E C M_{t-1}$ & $-0.652^{\star \star \star}$ & \\
\hline$F_{p S S}$ & 19.25 & & $F_{p S S}$ & 11.84 & \\
\hline$W_{L R}$ & $9.31(0.007)$ & & $W_{L R}$ & $8.88(0.002)$ & \\
\hline$W_{S R}$ & $15.01(0.001)$ & & $W_{S R}$ & $12.19(0.001)$ & \\
\hline \multicolumn{6}{|c|}{ Panel - D: Residual Diagnostic test } \\
\hline$R^{2}$ & 0.74 & & $R^{2}$ & 0.72 & \\
\hline$F_{\text {statistics }}^{2}$ & $7.04^{\star \star \star}$ & & $F_{\text {statistics }}^{2}$ & $7.37^{\star \star *}$ & \\
\hline$x_{\text {Autocorrelation }}^{2}$ & $1.97(0.19)$ & & $x_{\text {Autocorrelation }}^{2}$ & $1.52(0.21)$ & \\
\hline$x_{\text {Heteroskedasticity }}^{2}$ & $0.45(0.95)$ & & $x_{\text {Heteroskedasticity }}^{2}$ & $1.12(0.26)$ & \\
\hline$x_{\text {Normality }}^{2}$ & $21.64(0.29)$ & & $x_{\text {Normality }}^{2}$ & $2.21(0.18)$ & \\
\hline$x_{R E S E T}^{2}$ & $0.52(0.26)$ & & $x_{R E S E T}^{2}$ & $1.43(0.15)$ & \\
\hline
\end{tabular}

Note 1: superscript "+," and "-" denote Positive and Negative Changes of the exchange rate and FDI, respectively.

Note 2. ${ }^{* * *}$ and ${ }^{* *}$ denote significance at the 1 and $5 \%$, levels, respectively

Note 3: $W_{L R}$ for Walt test to investigate long-run symmetry test, $W_{\mathrm{SR}}$ for Wald test short-run symmetry investigation.

Note 4: $F_{p s s}$ indicate test statistics for long-run cointegration.

Note 4: $\mathrm{L}^{+}$and $\mathrm{L}^{-}$indicate long-run coefficients.

Note 5: The critical value for $\mathrm{K}=1$ at $1 \%$ level of significant 6.84-7.84 extracted from Pesaran et al. (2001) 


\subsection{Granger-causality Test}

ARDL bound testing confirms the existence of long-run cointegration between exchange rate and FDI inflow along with two variables. It suggested that there should have at least one directional causality in the model. The causality test results reported in Table 5 .

For the long-run causality, the error correction term ECT (-1) should be negative and statistically significant. We observed that the coefficient of ECT (-1), in the equation, when FDI and exchange rate serves as the dependent variable, are negative. Thus, confirming the existence of long-run causality. Therefore, we can infer bidirectional causality between FDI inflows and exchange rate in Bangladesh. As expected, we also investigate short-run causality. The study revealed bidirectional causality between FDI and EX [FDI $\leftarrow \rightarrow \mathrm{EX}]$. Also, we found unidirectional causality from exchange rate to money supply $[\mathrm{EX} \rightarrow \mathrm{M}]$ and gross capital formation to exchange rate $[\mathrm{GCF} \rightarrow \mathrm{EX}]$.

Table 5: Granger-causality test results

\begin{tabular}{|c|c|c|c|c|c|c|c|}
\hline & \multicolumn{5}{|c|}{ Short-run Causality } & \multicolumn{2}{|r|}{ Long-run causality } \\
\hline Variables & $\Delta \ln F D I_{t-1}$ & $\ln E X_{t-1}$ & $\ln M_{t-1}$ & $\ln G C F_{t-1}$ & Direction & $\mathrm{ECT}(-1)$ & Inference \\
\hline $\operatorname{lnFDI} I_{t}$ & 0 & $0.009^{\star *}$ & 0.115 & 0.011 & \multirow{4}{*}{$\begin{array}{l}\text { FDI } \rightarrow E X, \\
E X \rightarrow M \text {, and } \\
\text { GCF } \rightarrow E X\end{array}$} & -0.601 & Long-run causality \\
\hline $\ln E X_{t}$ & $0.001^{* *}$ & 0 & 2.257 & $0.817^{* *}$ & & -0.354 & Long-run causality \\
\hline $\ln M_{t}$ & 0.899 & $0.955^{\star \star}$ & 0 & 0.858 & & 0.535 & \\
\hline $\operatorname{lnGCF_{t}}$ & $1.508^{* *}$ & 0.838 & 1.188 & 0 & & 0.356 & \\
\hline
\end{tabular}

Note1. " $\leftarrow \rightarrow$ " for bidirectional causality, and " $\rightarrow$ " for unidirectional causality, respectively.

Note $2:{ }^{* *} /{ }^{*}$ indicates level of significance at $1 \%$ and $5 \%$, respectively.

\section{Finding and Conclusion}

Finance literature provides ample evidence regarding exchange rate movement influence in every corner in the economy including exports, imports, international trade, aggregate production and purchasing power of the host country. However, a significant number of researchers concentrated on investigating the relationship between exchange rate and FDI inflows in the host country considering the wealth effect hypothesis proposed by Froot and Stein (1991). As a developing nation, Bangladesh experienced the FDI inflows in infrastructural development, industrialization, and capital market development over the past decades. Therefore, maintaining the flow of FDI, the regulatory authority initiated a number of financial reforms activities like financial market deregulation, corporate governance on banking sectors, monetary and fiscal policy formulation based on evaluating the macro-economic situation, and many more. The aim of this study is to gauge the dynamic relationship between FDI-exchange rates in Bangladesh for the period of 1974Q1 to 2016Q4. To investigate the linear relationship, we used the ARDL bound testing approach proposed by Pesaran et al. (2001) and to assess nonlinearity by using NARDL proposed by Shin et al. (2014).

The long-run model estimation results applying the ARDL bounds testing approach and nonlinear ARDL confirm the presence of long-run cointegration between FDI and exchange rate. We also found, under the ARDL bounds testing approach, the long-run coefficient of the exchange rate is positive and statistically significant. This is implying that real depreciation of host currency TK against USD attracts FDI. Our findings are supported by empirical studies including Görg and Wakelin (2001), and Blonigen (1997).
This finding also confirms the hypothesis of the wealth effects of FDI under the imperfect capital market proposition. To evaluate both long-run and short-run elasticities of the exchange rate and FDI, we have conduct two (02) different ARDL estimation considering the exchange rate and FDI as the dependent variable (see Table 3 ). We have also found that the exchange rate positively influences on inwards of FDI in Bangladesh. Finding also suggests real depreciation of TK against USD increases flow of FDI in the long run. On the other hand, inward FDI negatively influences the exchange rate. It indicates that the greater flow of FDI can cause real depreciation of the exchange rate in the economy.

Our findings evidently support the existence of an asymmetric relationship between exchange rate and inflows of FDI in Bangladesh for the period of 1974Q1-2016Q4 for both model (9) and (10). In the long run, for the model (9), we found that the negative change in the exchange rate is more significant than positive changes in the exchange rate. On the other hand, for the model (10), positive changes in FDI adversely affected the exchange rate. While the negative change in FDI flows has a positive influence on the exchange rate but the coefficient magnitude is less significant.

We also performed Granger-causality to gauge directional causality between exchange rate and FDI. The study revealed bidirectional causality between FDI and exchange rate both in the long run and in short-run. These findings suggest that any adjustment in either variable, the effects may can eminent effect in the economy. In a developing country like Bangladesh, inflows of FDI are immensely important; it is because FDI inflows in the economy ensure a continuous flow of long-term capital, technological transfer, and international competitiveness. Therefore, for macroeconomic stability, in particular, a 
stable exchange rate is the key for inflows of FDI in the economy, as we found asymmetric relationship both in the long-run and short-run. Asymmetric relations confirm one variable influence on another in either case.

\section{References}

Adhikary, B. K. (2011). FDI, trade openness, capital formation, and economic growth in Bangladesh: A linkage analysis. International Journal of Business and Management, 6(1), 16-28.

Ahamed, M. G., \& Tanin, F. (2010). Determinants of, and the Relationship between FDI and Economic Growth in Bangladesh (Bonn econ discussion papers no. 2010.1).

Ahmad, J., \& Harnhirun, S. (1996). Cointegration and causality between exports and economic growth: Evidence from the ASEAN countries. The Canadian Journal of Economics/Revue Canadienne d'Economique, 29, S413-S416.

Ali, U., Shan, W., Wang, J.-J., \& Amin, A. (2018). Outward foreign direct investment and economic growth in China: Evidence from asymmetric ARDL approach. Journal of Business Economics and Management, 19(5), 706-721.

Alvarado, R., Iñiguez, M., \& Ponce, P. (2017). Foreign direct investment and economic growth in Latin America. Economic Analysis and Policy, 56, 176-187. doi:10.1016/j.eap.2017.09.006

Ang, J. B. (2008). Determinants of foreign direct investment in Malaysia. Journal of Policy Modeling, 30(1), 185-189.

Anwar, S., \& Nguyen, L. P. (2010). Foreign direct investment and economic growth in Vietnam. Asia Pacific Business Review, 16(1-2), 183-202.

Arize, A. C., Malindretos, J., \& Igwe, E. U. (2017). Do exchange rate changes improve the trade balance: An asymmetric nonlinear cointegration approach. International Review of Economics \& Finance, 49, 313326. doi:10.1016/j.iref.2017.02.007

Baek, I.-M., \& Okawa, T. (2001). Foreign exchange rates and Japanese foreign direct investment in Asia. Journal of Economics and Business, 53(1), 69-84.

Bahmani-Oskooee, M., Halicioglu, F., \& Mohammadian, A. (2018). On the asymmetric effects of exchange rate changes on domestic production in Turkey. Economic Change and Restructuring, 51(2), 97-112.

Bahmani-Oskooee, M., \& Mohammadian, A. (2016). Asymmetry effects of exchange rate changes on domestic production: Evidence from Nonlinear ARDL Approach. Australian Economic Papers, 55(3), 181-191. doi:10.1111/1467-8454.12073

Bangladesh Bank. (2019). Data Archive. Retrieved August 10, 2019, from https://www.bb.org.bd/pub/annual/anreport/ar1617/index 1617.php
Bangladesh Bureau of Statistics. (2017). National accounts statistics: Bangladesh Bureau of Statistics. Dhaka, Bangladesh: Bangladesh Bureau of Statistics.

Bari, M. (2013). Foreign direct investment and economic growth In Bangladesh and India: A comparative study. South Asian Journal of Management, 20(1), 7-37.

Bayoumi, T., Bartolini, L., \& Klein, M. (1996). IV foreign direct investment and the exchange rate. Exchange Rate Movements and Their Impact on Trade and Investment in the APEC Region(pp.45-145). Washington, DC: Internaltinal Monetary Fund.

Belloumi, M. (2014). The relationship between trade, FDI and economic growth in Tunisia: An application of the autoregressive distributed lag model. Economic Systems, 38(2), 269-287. doi:10.1016/j.ecosys.2013.09.002

Bildirici, M., \& Ozaksoy, F. (2017). The relationship between woody biomass consumption and economic growth: Nonlinear ARDL and causality. Journal of Forest Economics, 27, 60-69. doi:10.1016/j.jfe.2017.01.002

Blonigen, B. A. (1997). Firm-specific assets and the link between exchange rates and foreign direct investment. The American Economic Review, 87(3), 447-465.

Boateng, A., Hua, X., Nisar, S., \& Wu, J. (2015). Examining the determinants of inward FDI: Evidence from Norway. Economic Modelling, 47, 118-127.

Borensztein, E., \& De Gregorio, J. (1995). How Does Foreign Direct Investment Affect Economic Growth, 45(1), 115-135

Borensztein, E., De Gregorio, J., \& Lee, J.-W. (1998). How does foreign direct investment affect economic growth? Journal of International Economics, 45(1), 115-135.

Campa, J., \& Goldberg, L. S. (1995). Investment in manufacturing, exchange rates and external exposure. Journal of International Economics, 38(3), 297-320.

Campa, J. M. (1993). Entry by foreign firms in the United States under exchange rate uncertainty. The Review of Economics and Statistics, 75(4), 614-622.

Clarke, R., \& Ioannidis, C. (1994). Mergers and excess deposits: Some evidence for the UK. International Journal of the Economics of Business, 1(3), 377-385.

Crespo, N., \& Fontoura, M. P. (2007). Determinant factors of FDI spillovers-what do we really know? World Development, 35(3), 410-425.

Cushman, D. O. (1985). Real exchange rate risk, expectations, and the level of direct investment. The Review of Economics and Statistics, 67(2), 297-308.

Dees, S. (1998). Foreign direct investment in China: Determinants and effects. Economics of Planning, 31(23), 175-194.

Dewenter, K. L. (1995). Do exchange rate changes drive foreign direct investment? Journal of Business, 68(3), 405-433.

Dickey, D. A., \& Fuller, W. A. (1979). Distribution of the estimators for autoregressive time series with a unit root. Journal of the American Statistical Association, 
74(366a),

$427-431$. doi:10.1080/01621459.1979.10482531

Ericsson, J. (2001). On the causality between foreign direct investment and output: A comparative study. The International Trade Journal, 15(1), 1-26. https://doi.org/10.1080/088539001300005431

Fousekis, P., Katrakilidis, C., \& Trachanas, E. (2016). Vertical price transmission in the US beef sector: Evidence from the nonlinear ARDL model. Economic Modelling, 52, 499-506.

Froot, K. A., \& Stein, J. C. (1991). Exchange rates and foreign direct investment: An imperfect capital markets approach. The Quarterly Journal of Economics, 106(4), 1191-1217.

Ghatak, S., \& Siddiki, J. U. (2001). The use of the ARDL approach in estimating virtual exchange rates in India. Journal of Applied Statistics, 28(5), 573-583.

Goldberg, L. S. (2009). Exchange rates and foreign direct investment. The Princeton Encyclopedia of the World Economy, 1, 393-396.

Görg, H., \& Wakelin, K. (2001). The impact of exchange rate variability on US direct investment (Research Paper No. 2001.22). Leverhulme Centre for Research on Globalisation and Economic Policy, University of Nottingham, Nottingham.

Gui-Diby, S. L. (2014). Impact of foreign direct investments on economic growth in Africa: Evidence from three decades of panel data analyses. Research in Economics, 68(3), 248-256. doi:10.1016/j.rie.2014.04.003

Harford, J. (2005). What drives merger waves? Journal of Financial Economics, 77(3), 529-560.

Harris, R. S., \& Ravenscraft, D. (1991). The role of acquisitions in foreign direct investment: Evidence from the US stock market. The Journal of Finance, 46(3), 825-844.

Hye, Q. M. A. (2011). Financial development index and economic growth: Empirical evidence from India. The Journal of Risk Finance, 12(2), 98-111.

Howitt, P., \& Aghion, P. (1998). Capital accumulation and innovation as complementary factors in long-run growth. Journal of Economic Growth, 3(2), 111-130.

Hussain, M., \& Haque, M. (2016). Foreign direct investment, trade, and economic growth: An empirical analysis of Bangladesh. Economies, 4(2), 1-14. doi:10.3390/economies4020007

Iamsiraroj, S. (2016). The foreign direct investmenteconomic growth nexus. International Review of Economics \& Finance, 42, 116-133. doi:10.1016/j.iref.2015.10.044

Iamsiraroj, S., \& Ulubaşoğlu, M. A. (2015). Foreign direct investment and economic growth: A real relationship or wishful thinking? Economic Modelling, 51, 200-213. doi:10.1016/j.econmod.2015.08.009

Katrakilidis, C., \& Trachanas, E. (2012). What drives housing price dynamics in Greece: New evidence from asymmetric ARDL cointegration. Economic Modelling, 29(4), 1064-1069.
Klein, M. W., \& Rosengren, E. (1994). The real exchange rate and foreign direct investment in the United States: relative wealth vs. relative wage effects. Journal of International Economics, 36(3), 373-389.

Kohlhagen, S. W. (1977). Exchange rate changes, profitability, and direct foreign investment. Southern Economic Journal, 44(1), 43-52.

Kwiatkowski, D., Phillips, P., Schmidt, P., \& Shin, Y. (1992). Testing the null hypothesis of stationarity against the alternative of a unit root: How sure are we that economic time series have a unit root? Journal of Econometrics, 54(1-3), 159-178.

Lily, J., Kogid, M., Mulok, D., Thien Sang, L., \& Asid, R. (2014). Exchange rate movement and foreign direct investment in asean economies. Economics Research International, $2014, \quad 1-10$. http://dx.doi.org/10.1155/2014/320949

Lin, C.-H. (2011). Exchange rate exposure in the Asian emerging markets. Journal of Multinational Financial Management, 21(4), 224-238.

Lipsey, R. E., Feenstra, R. C., Hahn, C. H., \& Hatsopoulos, G. N. (1999). The role of foreign direct investment in international capital flows. In M. Feldstein (ed.), International Capital Flows (pp. 307-362). Chicago, IL: University of Chicago Press. Retireved from https://www.nber.org/chapters/c9801.pdf

Liu, H. Y., \& Deseatnicov, I. (2016). Exchange rate and Chinese outward FDI. Applied Economics, 48(51), 49614976.

Liu, W. (2010). Determinants of FDI inflows to China: An empirical analysis of source country characteristics. Preceddings of 2010 Taipei International Conference on Growth, Trade and Dynamics (pp. 1-18), Taipei, Taiwan.

MacDermott, R. (2008). Linking exchange rates to foreign direct investment. The International Trade Journal, 22(1), 3-16.

Ministry of Finance. (2016). Bangaledshe economic review 2016. Bangladesh Government Press Tejgaon, Dhaka 1208.

Narayan, P. (2004). Reformulating critical values for the bounds F-statistics approach to cointegration: an application to the tourism demand model for Fiji. Melbourne, Australia: Monash University. Retrieved from https://trove.nla.gov.au/version/13127742

Narayan, P. K. (2005). The saving and investment nexus for China: evidence from cointegration tests. Applied Economics, $\quad 37(17), \quad 1979-1990$. doi:http://dx.doi.org/10.1080/00036840500278103

Narayan, S., \& Narayan, P. K. (2005). An empirical analysis of Fiji's import demand function. Journal of Economic Studies, $\quad 32(2), \quad 158-168$. doi:10.1108/01443580510600931

Osinubi, T. S. (2002). Does stock market promote economic growth in Nigeria. The ICFAI Journal of Applied Finance, 10(3), 17-35.

Ouattara, B. (2006). Foreign aid and fiscal policy in Senegal. Journal of International Development, 18,1105-1122. 
Pain, N., \& Van Welsum, D. (2003). Untying the Gordian knot: The multiple links between exchange rates and foreign direct investment. Journal of Common Market Studies, 41(5), 823-846.

Pesaran, H. H., \& Shin, Y. (1998). Generalized impulse response analysis in linear multivariate models. Economics Letters, 58(1), 17-29. doi:https://doi.org/10.1016/S0165-1765(97)00214-0

Pesaran, M. H., Shin, Y., \& Smith, R. J. (2001). Bounds testing approaches to the analysis of level relationships. Journal of Applied Econometrics, 16(3), 289-326. doi:10.1002/jae.616

Phillips, P. C. B., \& Perron, P. (1988). Testing for a unit root in time series regression. Biometrika, 75(2), 335-346. doi: https://doi.org/10.1093/biomet/75.2.335

Phillips, S., \& Ahmadi-Esfahani, F. Z. (2008). Exchange rates and foreign direct investment: Theoretical models and empirical evidence. Australian Journal of Agricultural and Resource Economics, 52(4), 505-525.

Polat, B., \& Payaslıoğlu, C. (2016). Exchange rate uncertainty and FDI inflows: The case of Turkey. AsiaPacific Journal of Accounting \& Economics, 23(1), 112129.
Pradhan, R. P. P. (2009). The FDI-led-growth hypothesis in ASEAN-5 countries: Evidence from cointegrated panel analysis. International Journal of Business and Management, 4(12), 153-164.

Qamruzzaman, M. (2015). Determinants of Foreign Direct Investment (FDI): Evidence from Bangladesh. Pacific Business Review International, 7(10), 97-105.

Resende, M. (2008). Mergers and acquisitions waves in the UK: a Markov-switching approach. Applied Financial Economics, 18(13), 1067-1074.

Shapiro, D., \& Globerman, S. (2003). Foreign investment policies and capital flows in Canada: A sectoral analysis. Journal of Business Research, 56(10), 779-790.

Shin, Y., Yu, B., \& Greenwood-Nimmo, M. (2014). Modelling asymmetric cointegration and dynamic multipliers in a nonlinear ARDL framework. In R. Sickles, \& W. Horrace (eds), Festschrift in Honor of Peter Schmidt (pp. 281-314). New York, NY: Springer.

Umoh, O. J., Jacob, A. O., \& Chuku, C. A. (2012). Foreign direct investment and economic growth in Nigeria: An analysis of the endogenous effects. Current Research Journal of Economic Theory, 4(3), 53-66. 